\title{
AN OUTLINE ON PHYSICAL TRAINING QUALITY FEATURES RELATED TO COACHING ROLES IN PEAK PERFORMANCE ACTIVITIES
}

\author{
Ioan Alexandru, HULPUŞ \\ "Lucian Blaga" University of Sibiu, Sibiu, Romania, email: alex@ hulpus.ro
}

\begin{abstract}
The growth of sports accompanied by the increasing number of quality competitions have become a matter of interest for those involved with the study of methodological and theoretical approaches with application in sports and performance activities. No organization or activity, regardless of their profile, can achieve a high level of efficiency on their own, disregarding basic management element, rules, principles, laws, techniques and methods. Due to social needs they meet and their purpose, the activities in sports organizations, among which training stands top priority, claim a leader.

A coach must be both manager and leader, be an inspiration for his team and a supervisor as well. He has to be disciplined, in good balance, a thorough assessor of people and activities, very efficient by his capacity to scout talent in people and make the best of it.

KEY WORDS: quality, coaching, sport activities, coach, leader, performance
\end{abstract}

\section{INTRODUCTION TO QUALITY}

"Quality is not everything, but there is nothing without quality." [10].

Quality is a basic feature of value to all of us as human beings, it is a concept to be applied to all branches of sports without exception. Quality has become a necessity in all fields of our everyday life. "Quality" as a term derives ethimologically from the Latin "quails" which means way of life.

The overall evolution of quality as a concept, along with the constant growth of social-economic relationships have been an appealing subject for study and research. Due to its complexity, the numberless definitions of quality will never be exhaustive enough to render the innermost essence of the term, therefore there is always room for additional data.

We select few suggestive definitions:

-meeting necessity; consumer's degree of satisfaction; low price for a given use; capacity to fulfil needs; the set of means to get a reliable product; compliance with a given model, fully meeting the needs of beneficiary, degree of social use of the product, the degree to which it fulfils the needs according to its initial design and compliance to restrictions and social rules within the context of economic efficiency. [8]

The concept of quality is not merely philosophical, but related to economy as well. The impact of quality upon economy has had other type of consequences than those in what Philosophy is concerned. The current concept of quality has become of general interest to all organizations. Be it a philosophical or economic term, quality is necessary and it supports its value as a scientific field that has the capacity to solve nowadays issues.
The management of quality implemented in sports units involves planning, coordination, organization, control and safety along with a constant improvement of specific activities and image

\section{THE RELATIONSHIP BETWEEN PERFORMANCE TRAINING AND EFFICIENCY IN SPORTS UNITS}

Any sport unit can be efficient if it is positively related to its targets. Efficiency in sports is measured by won matches in a given period of time relying on the manner the participants understand and take over responsibilities. The coach takes over responsibility for setting roles and objectives through open communication on his expectations from each member of the team.

In sports as in any other activity, a manager plans work in order to achieve efficiency, constantly considering people's needs and unit's profile and targets as well.

An increased growth in performance is determined by constant scientific improvement and design of training.

The main target of a coach would be taking part in competitions, facing other opponents at a higher level to establish certain ranks and achieving peak performance: a tool of assessment in sports. [1]

Although competitions are to be regarded as the ultimate testing ground for athlete's efficiency and the way they weigh and improve energy, techniques and psychological features, training is the most important link in the whole process. Due to complex activities that are part of trainings, management strategies must be performance-oriented in order to improve skills. There is an imperative necessity for the most adequate techniques required by competition rules, motivational methods, planning, measuring effort and recovery to meet further competition standards. Within this given framework, the use of scientific 
management in training could mean a better evaluation and use of the whole activity. Management in training involves methods and techniques used by a coach as an operational manager, strong personality in training processes which are specific to each branch of activity, age group and athletic fitness. The methods employed by a coach to combine management skills applied to training, have a substantial influence upon outcome and effects. A high level of performance involves both wellstructured methods and techniques, besides intuition, experience or talent. Communication rules provided by the science of management can never be overlooked by a coach or any other highly positioned person within the structure of sports units.

These are the reasons for a coach to be motivated to practice and attempt to apply his managerial skills and to establish an efficient background for performance.

Managerial skills do not belong to a certain person, they are merely a set of skills, attitudes, features equally shared by the whole organization.

A coach does not only coordinate activities, but also holds responsibilities and obligations in achieving a goal, which certainly includes leadership as a mission.

Performance in sports involves well-coordinated coaching activity, thorough planning, the best selected number of training hours, planned recovery, technique and tactic drills as starting points for an athlete's way of life. Nevertheless, a carefully planned training session involves the presence of complex data on physical, technique, tactics details and opponent's potential degree, as well. [2]

We notice that a coach is among other things, a source of inspiration to all staff. This offers a better perspective of a coach figure who deals, coordinates people, and takes over the lead. Efficiency is strongly related to the use of own knowledge, behavior and attitudes as a model to all athletes in order to achieve their goals in general, and of an efficient training process in particular

Coaches must be both crafty leaders and managers, with a good sense of team building, eager to compete and succeed in a world that demands attitude and cooperation skills.

\section{MANAGEMENT PECULIARITIES IN SPORTS TRAINING}

Certo finds that a managerial process develops and improves gradually inside and outside sports units as follows: situational diagnosis, planning and making decisions, organization, activity coordination, outcome control and assessment. It is universal, the outcome of human reasoning and practice with a specific goal to achieve growth and welfare. [1]

Management in training has the purpose to increase its quality with the help of specific methods and means of operational management. The outcome of this interdisciplinary research provides models of practical and efficient approach of managerial processes regarding training planning, good educational framework, training leading and assessing.

\subsection{Planning training programs}

Forecasting, as set of work processes for setting the main objectives, resources and the ways of implementation, can be found as a peculiar form of sport management function in sport activities planning and training programs, as well. Planning training sessions must contain the answer to the following question: what has to be done in training routine? [7]
Planning training is a process that forecasts progress and outcome scores through progressive physical adjustment to effort, and it is mainly designed to fit the model of the following competition

Forecasting supposes minute activities, thorough analysis of previous outcome, current systems, activity goals and available resources.

In the latter stage, managers and coaches mostly, have to have in view material and financial resources, information, athlete's potential and their level of performance. The design of a realistic plan must involve athlete's previous outcome scores, what their strengths and weaknesses are, in order to assess the real level of their performance and their general health check.

\subsection{Organizing training}

Organizing training consists in a series of managerial processes that are set and limit physical and intellectual work awarding responsibility to each member of the staff according to specific managerial criteria.

Practically speaking, someone within the organization has to answer to the question: Who and in what manner they make a contribution to training goals?

As mentioned above, training features as managerial and pedagogical process are leading training to all coaching stages, as operational manager and expert as well. Reaching training goals and improving athlete's motor skills and technical- tactical abilities, including optimizing performance are specific activities to any coach.

Few of these features will be his duty for a successful training. Training period, dates, venues and time tables should be set.

The role of a coach in the design and practice of training is of uttermost importance, regardless of the fact that any plan should require approval of national federations or any other body or board.

Once approved, the plan will be presented in front of all athletes. The coach needs to explain clearly his demands and expectations motivating his team to be active and respect all rules according to pre-established quality and quantity agreement

Efficiency of actual training activities is guaranteed by measures taken coaches in order to support the administrative staff of the unit where training takes place. Before starting training he must make sure the location is proper and functional in relation to the goals and the number of athletes present at that moment. Wellequipped fields and courts, proper locker rooms and court lines and markings are pre-requisites for any successful training.

We cannot disregard all tasks a coach has to fulfil, nevertheless, his main duty as an expert would be organizing the whole training. When he reaches this stage, a coach must check athletes' attendance and mostly health condition, their adjustment to planned effort, in quality and quantity, their involvement from the start until the end of the training lesson.

Being part of any competition involves organizing responsibilities a coach must possess. However, coaches have been lately slightly relieved of some managerial responsibilities such as planning trips, meals, accommodation, and local transportation. Under these circumstances, the coach holds the most important role in coordinating and supervising these tasks, mostly focusing on his expertise as trainer, and mentor of his athlete or team. 


\subsection{Conducting training sessions}

Conducting training sessions consists of a set of work processes that gather together decision making and actions in units, in what previous forecasting and organization are concerned.

It is a less formal stage when conducting gets very dynamic. Its success relies on coach's ability to employ and make use of his managerial skills and style.

Practically speaking, the coach must be able to follow each athlete's capacity and reactions to planned effort and to adjust intensity at its best to fit his goals.

The bedrock of coordination lies in communication, which provides constant exchange of information.

\subsection{Training and motivation}

Training in the context of managerial framework is a set of work processes which determines athletes to involve and be a part of making decisions and achieving planned goals, on motivational grounds.

The questions any coach should answer at this stage, would be: What motivates athletes? Why do athletes participate at sport events?

One fundamental reason would be motivation. According to professors Nicolescu and Verboncu motivation consists of correlations of needs, goals and interests of staff in a unit or athletes, in our case, with the purpose to achieve pre-established objectives, skills and responsibilities. [7]

Motivation supposes multiple roles which can vary in intensity regardless of activity, but in the branches of sports we can speak about a perspective changing feature

The managerial input is of tremendous importance in this process, the most direct role being held for efficient and quality practice. Motivating athletes is a condition for good training, its level and quality being strongly connected to other managerial tasks such as forecasting, organizing, coordinating and monitoring-assessing as well.

Motivation means organizing through coaching and mobilization. Their goals and aspirations are the fuel for action, creativity, energy, regarded all as the best human resource that leads to performance. Its effects are to be shared by all organization.

Motivation fulfils individually, it is a scale that offers a perspective on satisfactory or unsatisfactory activities of each person in a unit. The more motivated he feels, the higher his ability to develop and progress faster.

In conclusion, motivation represents a major part of managerial patterns. It is a systematic, endless process of training which is adjusted to each individual and task specificity. According to the attitude exhibited in front of people, coaches may influence his staff either in a positive or negative way.

Positive motivation is preferred in most situations due to its impact upon athletes and working environment. The coach owes all tools and means, material and financial resources, moral and financial rewards and fame.

Negative motivation consists of threats, it lowers the level of self-esteem and satisfaction in athletes if they are not active during training lessons. Measures to be taken under these circumstances would consist of salary cuts, un-awarded prizes and bonuses, etc.
The coach must constantly apprehend motivation theories, to be a good reader of human characters and conduct the whole motivation process in stages that would be representative for each and every athlete.

One representative motivation theory would be in this way Maslow's theory which designs a scale of 5 stages to reflect needs starting with the basic physiological ones and ending with upper levels such as self-esteem and the need of selfaccomplishment.

Due to specific theories, motivation must be complex and combine various incents given that people have different reactions in front of them. Motivation has to vary according to each person's peculiarities and also it has to be gradual and strongly related to pre-established goals and their accomplishment. [3]

We emphasize the idea that general management and motivation processes cannot be undergone by the book and following the pre-established models, regardless of rich contents of motivation theories.

It is the coach's job to adjust these complex processes to each unit, activity and human factor in particular. The knowledge of conducting and leading must be assessed according to coaching skills employed for a certain goal of achieving successful objectives, in harmonious environments.

\subsection{Assessment and control}

Specific literature sources define the stages of assessment and control as sets of processes that measure and compare athletic evolution and outcome scores achieved and compared to initial standards in order to lower differences for a positive approach.

Therefore coaches must answer to the following question: what are the outcomes of training?

Normally, control stages start by assessing training outcomes following athlete's evolution and performance. Coaches will assess activities as main source to draw reliable conclusions in any starting point for further objectives.

Coaches must employ the most relevant data to follow athletes' attendance and involvement in all training lessons, they must assess outcomes in control tests and regular health examination results.

Based on relevant results provided by the tests mentioned above, coaches will assess efficiency related to initial pre-established objectives and standards.

A final assessment stage spots irregularities during trainings and isolates them in order to set their cause and finally adjust correct training programs.

Control activities must be preventive, aim to foresee inaccuracy, attempt to correct irregularities, and corrective at the same time in order to make right decisions in case negative situations occur.

Coaches must react as managers and constantly assess and keep under control all activities during training lessons, competitions or other type of activities, for an efficient expert proves a good knowledge of his students from all points of view: as athletes, professionally, socially and morally. [11]

Recently, the coach's role as a special category of manager became the object of study for many specialists in the field of management. They observe that "manager" is viewed in variously stances as a team captain, parent, steward, battle commander, fountain of wisdom, poker player, group 
spokesperson, gatekeeper, minister, drill instructor, facilitator, initiator, mediator, navigator, candy store-keeper, linchpin, umbrella-holder, and everything else between nurse and Attilathe-Hun, but not as a coach. The actual needs require precisely to view the manager as a coach, and as a creator of a culture for coaching. The advantages of coaching are obvious, corporate managers must realize that individuals and teams generally perform better with a coach. The beneficial effects of coaching on a player's performance derive almost solely from the nature of the coach-player relationship and the communication (speaking and listening) that occur within that relationship. Much of business's focus on coaching has been in translating sports coaching into techniques for business management, especially techniques to motivate people, train them in job skills, or improve management development. In nearly all cases, the orientation is that the "superior" is acting as a coach who "directs" the players (or teams) to higher levels of performance. [4], [9]

\section{CONCLUSIONS}

Coaches are key figures in organization structures, holding the leading position during selection processes, training lessons, education, being the main provider of motivation in achieving goals, efficiency and high performance. Under these circumstances, coaches hold responsibility as leaders and reference position in the branch of sports.

Efficient training leadership and management would be appreciated both globally and individually. Positive work environments are always reflected upon global activities as a result of constructive relationships, mutual respect, great communication between coaches and students and peak performance-directed activities.

\section{REFERENCES}

1. Apostu, A.P., Îmbunătățirea managementului competiției sportive. Teză de doctorat, Cluj Napoca (2010)

2. Bompa O,T - Teoria şi metodologia, periodizarea antrenamentului. CNFPA, Bucureşti (2001)

3. Burduş, E., Căprărescu, Ghe., Fundamentele managementului organizaţiei, Ed. Economică, București (1999),

4. Evered, R., Selman, J.C., Coaching and the Art of Management, articol disponibil pe www.sciencedirect.com

5. HG 343/2011 privind aprobarea Statutului antrenorului, publicată în Monitorul Oficial nr.301/2011

6. Maslow, A.H., Motivation and personality. New York: Harper, 1954

7. Nicolescu, Ov., Verboncu I., Management, Editura Economică, ed. A III-a revizuită, Bucureşti, (1999)

8. Oprean, C.-Managementul calităţii, Ed.Univ.”Lucian Blaga", Sibiu, (2002)

9. Orth C.D., Wilkinson H.E, Benfari R.C. The Manager,s role as a Coach and Mentor,(2014) articol disponibil pe www.sciencedirect.com

10. Peters T., Waterman R.- "In search of Excellence", HarperCollins Publishers, London, (1982)

11. Sanislav Mihai, „Management în educaţ̧ie fizică şi sport”, Editura “Alma Mater", Sibiu, (2006) 